\title{
Effect of packaging on lipid oxidation, sensory and color attributes of the value added mutton meat balls during refrigeration
}

\begin{abstract}
The present work was conducted to develop the functional mutton meat balls (MMB) by incorporation of tomato powder (TP).mMB developed with the incorporation of TP at the level of $3 \%$ and $6 \%$ were packaged in laminates under normal and vacuum conditions. The product was analysed at three storage intervals $(0,10 \& 20$ days $)$ under refrigeration $\left(4 \pm 1{ }^{\circ} \mathrm{C}\right)$. The vacuum packed product showed significantly $(\mathrm{p} \leq 0.05)$ higher acceptability than normal package. The overall acceptability of mMB under normal conditions decreased significantly $(\mathrm{p} \leq 0.05)$ than vacuum package during storage. Total phenolic content and DPPH scavenging activity showed a significant $(p \leq 0.05)$ decrease with storage time. TBARS value and FFA (\%) increased to lesser extent in vacuum packed comparatively to normal packed $\mathrm{mMB}$ during storage. The proximate values were better retained in vacuum packed than normal packed $\mathrm{mMB}$ during storage.
\end{abstract}

Volume 7 Issue 3 - 2017

\author{
Sajad Ahmad Mir, Farooq Ahmad Masoodi \\ Department of Food Science and Technology, University of \\ Kashmir, India
}

\begin{abstract}
Correspondence: Farooq Ahmad Masoodi, Department of Food Science and Technology, University of Kashmir, Hazratbal, Srinagar, Jammu \& Kashmir, India, Pin Code: 190006, Tel +919419135872, Email masoodi_fa@yahoo.co.in
\end{abstract}

Received: October 05, 2017| Published: November 15, 2017

Keywords: lipid, vacuum, laminates, mutton, meat

Abbreviations: MDA, malon di aldehyde; TBARS, thio barbituric acid reactive substances; FFA, free fatty acids; TPC, total phenolic content; GAE, gallic acid equivalent; ANOVA, analysis of variance

\section{Introduction}

Demand for nutritious, healthy and RTE (ready to eat) meat and chicken products with functional values is increasing all over the world. The colour of RTE mutton products is one of the important attributes for consumer preference and its acceptability. Use of synthetic colorants in meat products is responsible for various allergic reactions ${ }^{1}$ and therefore consumers prefer naturally derived colorants. Tomatoes which are rich sources of lycopene, may act as suitable candidate to be used as natural colorant in the processed mutton meat products. Besides this tomatoes are a good source of antioxidants and there by becoming one of fast favorite foods. Apart from imparting color to processed meat products, it is supposed to increase their functionality. These value added product can thus prevent various lifestyle diseases including obesity, CVDs, diabetes, atherosclerosis, degeneration of brain, certain kind of cancers and help in improving mental function as humans age. ${ }^{2}$ Previous studies reported the use of tomato products and lycopene as antioxidants in meat products, such as tomato powder in frankfurters. ${ }^{3}$ Lycopene addition from natural sources to processed meat could lead to product with better taste, enhanced color and with a well health benefits. Lycopene addition to meat products will result in functional food, which will replace use of chemical preservative addition in minced meat products. Utilization of the tomato powder into the processed mutton meat products was supposed to fill the technological, economical and functional gap between the fruit and meat processing industries. The characteristics of mutton meat for processing into value added products are also out-standing. Mutton meat is the healthiest meat, known for human consumption because it is low in calories and cholesterol. Mutton meat is well comparable to other meats in many of the physicochemical, nutritional, functional properties and palatability attributes. Furthermore, its utility in meat processing is on increase because of higher content of lean meat and less fat. The aim of the present work was therefore to develop the functional meat products in order to lessen the various diseases occurring due to consumption of high fat meat products.

\section{Materials and methods}

\section{Material}

The meat from the lamb, slaughtered by the traditional hallal method was procured from a local market of Hazratbal, Srinagar and brought to the Department of Food Science and Technology (DFST), University of Kashmir. Fresh tomatoes were purchased from local market and were brought to DFST, University of Kashmir.

\section{Chemicals and reagents}

Standard chemicals and reagents used for various assays were procured from Hi-Media Laboratories Pvt. Ltd., Mumbai, India. All the chemicals were of analytical grade and of $99 \%$ purity.

\section{Tomato powder (TP) preparation}

Fresh and mature tomatoes were washed with running tap water to remove the dirt and dust. Tomatoes were cut into halves and the internal content was cored off. The chopped pieces were then vacuum dehydrated. The dehydrated pieces having moisture content of 10$12 \%$ were powdered in a kitchen grinder (Prestige PWG, India). The powder obtained was then sieved using mesh size N0.6 and packed into HDPE bags and stored under refrigerated conditions. 


\section{Product development}

The mutton meat balls (MMB) were developed as per the procedure described by. ${ }^{4}$ External fat and visible connective tissues was trimmed off from the freshly meat by knife and then cutted into small pieces. The meat pieces along with fat $(10 \%)$ were minced in a meat mincer (Kenwoodmg470, India) to obtain meat emulsion. Fine paste of onion, garlic, and ginger were used as condiments to optimize a final level of $10 \%$ in the developed product. All the ingredients were mixed well with meat emulsion. The well prepared meat emulsion was then divided into four equal lots. The first lot left untreated served as control $(\mathrm{C})$, while TP was added to the second and third lot at the level of $3 \%\left(\mathrm{~s}_{1}\right)$ and $6 \%\left(\mathrm{~s}_{2}\right)$, respectively. The respective lots were developed into small balls, each weighing 40 gm and of size $55 \mathrm{~mm}$. The samples were then cooked separately in the gravy at temperature of $100^{\circ} \mathrm{C}$ for $20 \mathrm{~min}$. The finished product was hot filled in HDPE under normal and vacuum conditions. The product was stored under refrigerated $\left(4 \pm 1^{\circ} \mathrm{C}\right)$ conditions for storage studies.

\section{Proximate analysis}

AOAC, $2000^{5}$ method were followed for the determination of moisture, ash, protein and fat content. Moisture ( $\mathrm{g}$ water/100g sample) was determined by drying $3 \mathrm{~g}$ of sample at $100^{\circ} \mathrm{C}$ to constant weight. Ashing was performed at $500^{\circ} \mathrm{C}$ for $5 \mathrm{~h}$ (g ash $/ 100 \mathrm{~g}$ sample). Kjeldahl method was used for the estimation of protein ( $\mathrm{g}$ protein $/ 100 \mathrm{~g}$ sample) with or 6.25 as conversion factor for nitrogen to crude protein. Fat (g fat/100 g sample) was calculated by weight loss after extraction with petroleum ether as a running solvent in a sohxlet apparatus (Soxtec 2043, Foss, Sweden). AOAC, $2005^{6}$ methods was used for the estimation of crude fiber in fat free samples. The samples were mixed with boiling $\mathrm{H}_{2} \mathrm{SO}_{4}(1.25 \%)$. The samples were filtered, washed and the left over material were subjected to further treatment with boiling $\mathrm{NaOH}$ solutions $(1.25 \%)$. Alcohol was used to wash the residue and then transferred to pre-weighed crucible. The samples were dried in hot-air oven (NSW- $143-\mathrm{OSA}-1$, India) at $85-100^{\circ} \mathrm{C}$ and weighed. Dried residue was incinerated in a muffle furnace at $600^{\circ} \mathrm{C}$ for $2-3 \mathrm{~h}$. All parameters were tested in triplicate.

\section{Physicochemical properties}

TBARS value:mMB samples were analyzed for thiobarbituric acid reactive substances (TBARS) as per the method described by Du and Ahn. ${ }^{7} 10 \mathrm{~g}$ ofmMB was homogenized (wise TIS homogenizer HG$15 \mathrm{~A}$ ) with $50 \mathrm{ml}$ of $20 \%$ TCA for $2 \mathrm{~min}$ and the slurry obtained was undisturbed for $10 \mathrm{~min}$. The extract was filtered through Whatmann filter paper No.4. The extract $(3 \mathrm{~mL})$ obtained was mixed with equal volume of $0.1 \%(\mathrm{w} / \mathrm{v})$ TBA reagent in a test tube. Blank sample was prepared by mixing $3 \mathrm{~mL}$ of $20 \%$ TCA with equal volume of $0.1 \%$ TBA reagent. The content of each test tube was thoroughly mixed and boiled in a water bath till pinkish color was attained and the test tubes were allowed to cool down. The absorbance was measured by a spectrometer (HITACHI U-2900) at 532nm and TBA value was calculated by comparing the absorbance of test sample with a standard graph prepared by using a known concentration of malondialdehyde (MDA).

Free fatty acids (FFA): The procedure as described by Koniecko ${ }^{8}$ was used for determination of free fatty acids (FFA). $10 \mathrm{~g}$ of the mMB sample was homogenized (wise TIS homogenizer HG-15A) with chloroform $(30 \mathrm{~mL})$ in the presence of anhydrous $\mathrm{Na}_{2} \mathrm{SO}_{4}$. The filtrate (Whatmann No. 1) was titrated against $0.1 \mathrm{~N}$ alcoholic $\mathrm{KOH}$ using 2 drops of $0.2 \%$ phenolphthalein as an indicator. FFA content was calculated as,
FFA $(\%)=(0.1 \times$ vol. of $0.1 \mathrm{~N}$ alc. $\mathrm{KOH} \times$ meq. wt. of lactic acid $\times$ $0.282) \times 100$

\section{Sample weight $(\mathrm{g})$}

pH: The samples were analyzed for determination of $\mathrm{pH}$ as per the method described by Trout et al. (1992) using a digital $\mathrm{pH}$ meter (HI $2215 \mathrm{pH} / \mathrm{ORP}$ meter). 10g of sample was blended (wise TIS homogenizer HG-15A) with $50 \mathrm{~mL}$ of distilled water. All determinations were performed in triplicates.

Cooking yield: Cooking yield was determined by measuring the weight of $\mathrm{mMB}$ before and after cooking for each treatment in five replicates using electronic weighing balance (KERN, EMB 100-2, Germany) and determined as follows:

$$
\text { Cooking yield }(\%)=\frac{\text { Cooked weight }}{\text { Raw weight }} X 100
$$

Color measurement: The color of $\mathrm{mMB}$ was measured by Hunter Color Lab (Mini Scan XE Plus, model No. 45/0-L, Hunter Associates Laboratory, Reston, VA). Calibration of equipment was done using black and white tiles before color measurement. The mMB samples were placed onto the petri-dish for measurement. To avoid the external light, samples were covered with black container. The measurements were made in triplicate and average value was reported.

\section{Antioxidant properties}

Total phenolic content (TPC): TPC of $\mathrm{mMB}$ was estimated by the method as described by Singleton \& Rossi ${ }^{9}$ with minor modifications. $400 \mu \mathrm{L}$ of diluted sample were added to $2 \mathrm{~mL}$ of 1:10 diluted FolinCiocalteu reagent. To this mixture, $800 \mu \mathrm{L}$ of saturated $\mathrm{Na}_{2} \mathrm{CO}_{3}(75 \mathrm{~g} / \mathrm{L})$ was added. The absorbance of the mixture was recorded at $765 \mathrm{~nm}$ after $2 \mathrm{~h}$ of incubation at room temperature using spectrophotometer (HITACHI U-2900). Gallic acid $(0-500 \mathrm{mg} / \mathrm{L})$ was used for the standard calibration curve. The results were expressed as Gallic acid equivalent (GAE)/g weight of sample.

DPPH radical scavenging activity: DPPH method was used for radical scavenging activity by the procedure described by Blois. ${ }^{10}$ To $200 \mu \mathrm{L}$ supernatant obtained after the extraction, was added $1 \mathrm{~mL}$ of $0.2 \mathrm{~m} \mathrm{M}$ DPPH prepared in methanol. The final volume of mixture was made to $1000 \mu \mathrm{L}$ by adding distilled water. The mixture was then vortexed (Labnet, USA) and left undisturbed at room temperature $\left(22^{\circ} \mathrm{C}\right)$ for $30 \mathrm{~min}$. A mixture of $1 \mathrm{~mL}$ methanol and $1 \mathrm{~mL}$ of $\mathrm{DPPH}$ solution was used as control were as methanol alone was used as a blank. The absorbance of the solution was measured at $517 \mathrm{~nm}$ using a spectrophotometer (HITACHI U-2900). The scavenging activity of chicken meat samples against DPPH radical was expressed as percent of control and calculated as:

$\%$ inhibition of DPPH $=[1-$ (absorbance of sample/absorbance of control)] x 100

\section{Sensory evaluation}

Sensory evaluation of mMB was performed using the method as described by Deda et al., ${ }^{11}$ with suitable modifications. The sensory evaluation was carried out in the Department of Food Science and Technology by the faculty members and research scholars with an average age of 30-35years. Prior to evaluation, the mMB were warmed at room temperature $\left(25^{\circ} \mathrm{C}\right)$ for $1 \mathrm{~h}$ and coded. The sensorial characteristics including appearance, flavor, texture and overall acceptability form MB were evaluated. 9-point hedonic scale was 
used for sensory evaluation. Examinations for each sample were performed in triplicate.

\section{Statistical analysis}

Mean values, standard deviation and analysis of variance (ANOVA) were computed using a commercial statistical package SPSS 16 (SPSS, Inc., Chicago, IL). The data were then compared using Duncan's multiple range tests at $5 \%$ level of significance.

\section{Results and discussions}

\section{Proximate composition}

The mean value for proximate composition of $\mathrm{mMB}$ is given in Table 1. From the values it is clear that control recorded higher moisture content than treatment groups $\left(\mathrm{s}_{1}\right.$ and $\left.\mathrm{s}_{2}\right)$. The moisture content of treatments decreased concomitantly with the level of TP. $\mathrm{s}_{1}$ recorded significantly $(\mathrm{P} \leq 0.05)$ higher moisture retention $(67.74 \%)$. Decrease in the moisture content among treated products with increasing level of TP could be due to comparatively lower moisture content in TP. This is in accordance with the results obtained by ElGharably \& Ashoush ${ }^{12}$ who reported that moisture content of beef sausages decreased with the increasing level of pomegranate rind powder and red beet powder. Results of Table 3 also indicated that the crude fat value of control was higher than $\mathrm{s}_{1}$ and $\mathrm{s}_{2}$. Among the treatment groups fat content of $\mathrm{s}_{2}$ sample was significantly $(\mathrm{P} \leq 0.05)$ lower than $\mathrm{s}_{1}$. This decrease in fat content could be attributed to the increase in the level of TP.

Table I Proximate composition of value added mutton meat balls during refrigerated storage $\left(4 \pm 1^{\circ} \mathrm{C}\right)$

All values are mean \pm standard deviation of three replicates

Means in the same column with different superscripts differ significantly: $* \mathrm{P}<0.05$

$\mathrm{C}$ control without TP, $\mathrm{S}_{1}$ with $3 \% \mathrm{TP}, \mathrm{S}_{2}$ with $6 \% \mathrm{TP}$

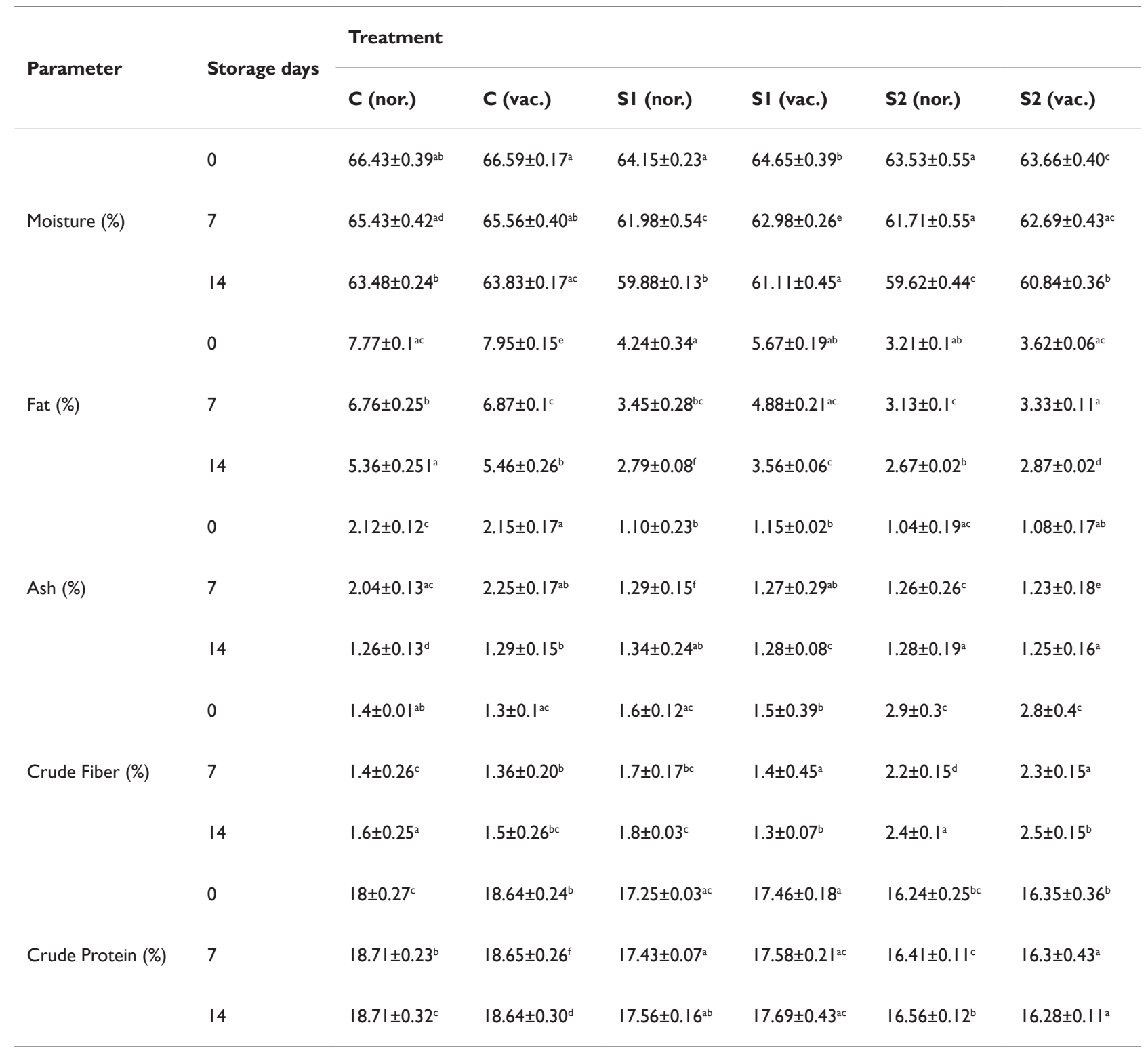

Citation: Mir SA, Masoodi FA. Effect of packaging on lipid oxidation, sensory and color attributes of the value added mutton meat balls during refrigeration. J Nutr Health Food Eng. 2017;7(3):30I-309. DOI: 10.15406/jnhfe.2017.07.00240 
Table 2 Physicochemical properties of value added meat balls during refrigerated storage $\left(4 \pm I^{\circ} \mathrm{C}\right)$

All values are mean \pm standard deviation of three replicates

Means in the same column with different superscripts differ significantly: $* P<0.05$

C control without TP, $S_{1}$ with $3 \%$ TP, $S_{2}$ with $6 \%$ TP

\begin{tabular}{|c|c|c|c|c|c|c|c|}
\hline \multirow{2}{*}{ Parameter } & \multirow{2}{*}{ Storage days } & \multicolumn{6}{|l|}{ Treatment } \\
\hline & & C (nor.) & C(vac.) & SI (nor.) & SI (vac.) & S2 (nor.) & S2 (vac.) \\
\hline \multirow{3}{*}{ TBARS } & 0 & $0.239 \pm 0.02^{c}$ & $0.235 \pm 0.08^{\mathrm{ab}}$ & $0.175 \pm 0.17^{\mathrm{ac}}$ & $0.166 \pm 0.23^{c}$ & $0.159 \pm 0.26^{\mathrm{ab}}$ & $0.145 \pm 0.32^{\mathrm{a}}$ \\
\hline & 7 & $0.678 \pm 0.46^{a}$ & $0.650 \pm 0.32^{\mathrm{b}}$ & $0.578 \pm 0.16^{\mathrm{ac}}$ & $0.547 \pm 0.09^{a}$ & $0.530 \pm 0.02^{\mathrm{a}}$ & $0.525 \pm 0.03^{c}$ \\
\hline & 4 & $0.986 \pm 0.43^{a}$ & $0.923 \pm 0.04^{b}$ & $0.89 I \pm 0.27^{a}$ & $0.756 \pm 0.03^{a c}$ & $0.730 \pm 0.02^{c}$ & $0.720 \pm 0.04^{f}$ \\
\hline \multirow{3}{*}{ FFA } & 0 & $0.19 \pm 0.02^{\mathrm{e}}$ & $0.17 \pm 0.02^{\mathrm{ac}}$ & $0.15 \pm 0.25^{c}$ & $0.12 \pm 0.12^{\mathrm{b}}$ & $0.13 \pm 0.09 c$ & $0.09 \pm 0.09^{d}$ \\
\hline & 7 & $0.28 \pm 0.34^{d}$ & $0.21 \pm 0.25^{\mathrm{a}}$ & $0.21 \pm 0.17^{f}$ & $0.16 \pm 0.33^{a}$ & $0.19 \pm 0.23^{\mathrm{ac}}$ & $0.16 \pm 0.2^{f}$ \\
\hline & 14 & $0.43 \pm 0.25^{c}$ & $0.37 \pm 0.09^{b}$ & $0.33 \pm 0.06^{\mathrm{a}}$ & $0.27 \pm 0.18^{\mathrm{ab}}$ & $0.24 \pm 0.1 \mathrm{I}^{\mathrm{d}}$ & $0.20 \pm 0.25^{\mathrm{ab}}$ \\
\hline \multirow{3}{*}{$\mathrm{pH}$} & 0 & $5.95 \pm 0.05^{\mathrm{a}}$ & $5.73 \pm 0.02^{\mathrm{bc}}$ & $5.89 \pm 0.14^{b}$ & $5.69 \pm 0.02^{\mathrm{ac}}$ & $5.81 \pm 0.06^{f}$ & $5.67 \pm 0.04^{b}$ \\
\hline & 7 & $6.12 \pm 0.07^{b}$ & $5.92 \pm 0.09^{a b}$ & $6.08 \pm 0.05^{c}$ & $6.05 \pm 0.34^{c}$ & $6.04 \pm 0.03^{\mathrm{ab}}$ & $6.01 \pm 0.02^{c}$ \\
\hline & 14 & $6.53 \pm 0.07^{\mathrm{ac}}$ & $6.04 \pm 0.09^{b}$ & $6.31 \pm 0.17^{a}$ & $6.08 \pm 0.06^{a}$ & $6.26 \pm 0.04^{b}$ & $6.13 \pm 0.06^{\mathrm{a}}$ \\
\hline \multirow{3}{*}{ Cooking Yield } & 0 & $89.20 \pm 2.34^{\mathrm{a}}$ & $91.23 \pm 3.34^{c}$ & $92.16 \pm 5.4 I^{b}$ & $93.34 \pm 3.54^{b}$ & $92.67 \pm 4.35^{\mathrm{a}}$ & $93.19 \pm 3.36^{c}$ \\
\hline & 7 & $87.13 \pm 3.14^{a}$ & $90.76 \pm 4.4 I^{b}$ & $91.89 \pm 3.23^{d}$ & $92.01 \pm 2.52^{c}$ & $92.11 \pm 3.38^{d}$ & $92.34 \pm 2.4 \mathrm{I}^{\mathrm{a}}$ \\
\hline & 14 & $86.78 \pm 4.12^{b}$ & $90.43 \pm 2.19^{c}$ & $91.01 \pm 2.3 I^{a}$ & $91.10 \pm 4.17^{a}$ & $91.50 \pm 3.38^{c}$ & $91.89 \pm 4.13^{b}$ \\
\hline
\end{tabular}

Table 3 Color value of value added mutton meat balls during refrigerated storage $\left(4 \pm l^{\circ} \mathrm{C}\right)$

\begin{tabular}{|c|c|c|c|c|c|c|}
\hline Treatment & Storage days & $\mathbf{L}^{*}$ & $\mathbf{A}^{*}$ & B* & Hue & Chroma \\
\hline \multirow{3}{*}{$C$ (nor.) } & 0 & $47.24 \pm 0.07$ & $5.95 \pm 0.08$ & $8.15 \pm 0.02$ & $42.34 \pm 0.18$ & $10.08 \pm 0.05$ \\
\hline & 7 & $45.2 \pm 0.04$ & $4.65 \pm 0.06$ & $7.15 \pm 0.09$ & $44.00 \pm 0.31$ & $9.2 \pm 0.03$ \\
\hline & 14 & $42.34 \pm 0.09$ & $3.99 \pm 0.09$ & $6.15 \pm 0.08$ & $54.00 \pm 0.4 I$ & $8.0 \pm 0.05$ \\
\hline \multirow{3}{*}{ C (vac.) } & 0 & $47.28 \pm 0.07$ & $5.99 \pm 0.08$ & $8.15 \pm 0.02$ & $47.34 \pm 0.18$ & $10.08 \pm 0.07$ \\
\hline & 7 & $46.2 \pm 0.04$ & $4.95 \pm 0.06$ & $7.15 \pm 0.09$ & $49.00 \pm 0.31$ & $9.8 \pm 0.03$ \\
\hline & 14 & $43.34 \pm 0.09$ & $4.09 \pm 0.06$ & $6.15 \pm 0.08$ & $54.00 \pm 0.4 I$ & $8.7 \pm 0.05$ \\
\hline \multirow{3}{*}{$s_{1}$ (nor.) } & 0 & $47.9 \pm 0.07$ & $5.98 \pm 0.03$ & $8.87 \pm 0.03$ & $58.88 \pm 0.19$ & $10.50 \pm 0.08$ \\
\hline & 7 & $46.3 \pm 0.04$ & $5.86 \pm 0.04$ & $8.43 \pm 0.01$ & $59.14 \pm 0.22$ & $10.06 \pm 0.01$ \\
\hline & 14 & $45.8 \pm 0.03$ & $5.73 \pm 0.07$ & $8.11 \pm 0.17$ & $60.32 \pm 0.34$ & $9.87 \pm 0.04$ \\
\hline \multirow{3}{*}{$s_{1}$ (vac.) } & 0 & $51.3 \pm 0.01$ & $6.10 \pm 0.12$ & $9.99 \pm 0.13$ & $61.24 \pm 0.17$ & $10.67 \pm 0.12$ \\
\hline & 7 & $52.7 \pm 0.09$ & $5.98 \pm 0.17$ & $9.45 \pm 0.09$ & $61.56 \pm 0.29$ & $10.23 \pm 0.08$ \\
\hline & 14 & $53.1 \pm 0.02$ & $5.89 \pm 0.05$ & $9.08 \pm 0.03$ & $62.01 \pm 0.56$ & $10.04 \pm 0.05$ \\
\hline \multirow{3}{*}{$s_{2}$ (nor.) } & 0 & $50.99 \pm 0.01$ & $6.40 \pm 0.03$ & II.I5 150.03 & $61.43 \pm 0.15$ & $11.89 \pm 0.02$ \\
\hline & 7 & $48.89 \pm 0.01$ & $5.70 \pm 0.03$ & $9.1 \pm 0.08$ & $64.61 \pm 0.12$ & $9.36 \pm 0.14$ \\
\hline & 14 & $43.67 \pm 0.02$ & $5.50 \pm 0.04$ & $7.19 \pm 0.05$ & $68.81 \pm 0.18$ & $7.35 \pm 0.09$ \\
\hline \multirow{3}{*}{$s_{2}$ (vac.) } & 0 & $54.9 \pm 0.01$ & $6.50 \pm 0.03$ & II. I5 $5 \pm 0.03$ & $64.43 \pm 0.15$ & $11.80 \pm .02$ \\
\hline & 7 & $49.89 \pm 0.01$ & $6.10 \pm 0.03$ & $10.1 \pm 0.08$ & $67.61 \pm 0.12$ & $10.36 \pm 0.14$ \\
\hline & 14 & $46.67 \pm 0.02$ & $5.70 \pm 0.04$ & $9.19 \pm 0.05$ & $69.81 \pm 0.18$ & $8.35 \pm 0.09$ \\
\hline
\end{tabular}

Citation: Mir SA, Masoodi FA. Effect of packaging on lipid oxidation, sensory and color attributes of the value added mutton meat balls during refrigeration. J Nutr Health Food Eng. 2017;7(3):30I-309. DOI: 10.15406/jnhfe.2017.07.00240 
These results agree with those reported by Fernandez-Gines et al., ${ }^{13}$ in which the addition of raw and cooked albedo at any concentration and 2.5 or $5.0 \%$ decreased fat content in sausages. Verma et al., ${ }^{14}$ also observed a decrease in fat content of sheep meat nuggets on incorporation of guava powder. The protein content of control was found to increase non-significantly comparatively to treated samples which showed significant increase in protein value with the storage. This could be due to protein degradation and protein oxidation with the period of storage. Among the treatments, protein content significantly $(\mathrm{P} \leq 0.05)$ decreased with the increasing levels of TP. The lower protein content among the treatments could be due to the replacement of lean chicken meat by TP. Trout et al., ${ }^{15}$ observed similar results and reported that protein percent of low fat beef patties containing poly-dextrose and oat flour as texture modifying ingredients was significantly decreased. Similar results was also observed by Huang et al. ${ }^{16}$ in emulsified pork meat balls incorporated with rice bran at the level of 5\% and above. Ash content of treated sample was found to decrease with the increasing levels of TP, however $s_{2}$ showed significantly $(\mathrm{P} \leq 0.05)$ lower ash content. This was in agreement with the findings of Verma et al., ${ }^{14}$ who reported that the ash content of low fat chicken nuggets decreased with the increasing levels of apple pulp. Crude fiber content of control was found significantly $(\mathrm{P} \leq 0.05)$ lower in comparison to $\mathrm{s}_{1}$ and $\mathrm{s}_{2}$. However it was found to increase with the increasing levels of TP. This increase in crude fiber could be possibly due to the higher fiber content of TP. Fernandez-Gines et al., ${ }^{13}$ reported the utilization of lemon albedo, a major component of lemon peel as a source of dietary fiber increased the fiber content in bologna sausages.

\section{Physicochemical parameters}

Thiobarbituric acid reacting substances (TBARS) value: The data obtained for TBARS in case of $\mathrm{mMB}$ during the storage is given in Table 2. A significant $(\mathrm{P} \leq 0.05)$ effect of storage period was observed on TBARS values of both controls as well as in treated samples under aerobic packaging. TBARS values followed a significantly increasing trend from 0-day to 20-day in case of both control as well as treated $\mathrm{mMB}$. The increase in TBARS values on storage might be attributed to oxygen permeability of packaging material that led to lipid oxidation. TBARS values of $\mathrm{mMB}$ containing TP increased non-significantly throughout storage period and these values were well below the acceptable limits of $1-2 \mathrm{mg}$ malondialdehyde/ $\mathrm{Kg}$ meat. The values of TBARS form MB containing TP were lower than control samples on all days of storage for both aerobic and vacuum packaging. A comparatively slow increase in TBARS value of $\mathrm{s}_{2}$ might be due to increased fiber, polyphenols and carotenoid content which acted as antioxidant. The large amount of phenolics contained in rind powder extract may cause its strong antioxidant ability Li \& Banarjee et al., ${ }^{17,18}$ also reported similar results in goat meat nuggets containing broccoli powder extract. Also from the data presented in Table 2, no significant difference in TBARS value was observed between $4 \%$ TP treated mMB packed aerobically and under vacuum from $0-7$ storagedays. However TP treatment and vacuum packaging significantly $(\mathrm{P} \leq 0.05)$ decreased the TBARS value ofmMB as compared to control. Similar results were reported by Devatkal et al., ${ }^{19}$ in ground goat meat and nuggets treated with pomegranate peel extract and vacuum packaging.

Free fatty acids (FFA) value: The effect of TP treatment during storage on free fatty acids content (\% oleic acid) of the mMB is presented in Table 2. The overall FFA values of mMB increased gradually with increasing storage period. However the increase in FFA content was significant $(\mathrm{P} \leq 0.05)$ for 0 to 20days of storage in case of $\mathrm{mMB}$ packed aerobically. This might be due to progressive oxidation of lipids during storage. The results are in agreement with Kanatt et al., ${ }^{20}$ in chicken meat during chilled storage. FFA content was significantly $(\mathrm{P} \leq 0.05)$ lower in TP treated (aerobic and vacuum packaged) samples than the control. Vacuum packaging also significantly decreased the FFA (\%) in TP treated vacuum packaged $\mathrm{mMB}$ compared to TP treated aerobically packaged mMB. Our results are in agreement with Sahoo \& Anjaneyulu ${ }^{21}$ who worked on effect of natural antioxidants and vacuum packaging on the quality of buffalo meat nuggets during refrigerated storage.

pH value: The overall $\mathrm{pH}$ values of $\mathrm{s}_{1}$ and $\mathrm{s}_{2}$ had lower values than the control. Viuda-Martos et al., ${ }^{22}$ also reported that addition of orange dietary fiber in bologna sausages resulted in decreased $\mathrm{pH}$ of treatments compared with control. The $\mathrm{pH}$ increased non-significantly during refrigerated storage for first 10days for both control and $\mathrm{s}_{1}$ and $\mathrm{s}_{2}$ under both vacuum and aerobic packaging. This might be due to the accumulation of metabolites in the beginning by bacterial action in meat in addition to protein and amino acid degradation resulting in formation of ammonia and consequent increase in $\mathrm{pH}$. The results are in agreement with Georgantelis et al., ${ }^{23}$ in refrigerated pork sausages. From the data given in Table 2, it is also clear that the mean $\mathrm{pH}$ values of vacuum packaged control and TP treated $\mathrm{mMB}$ was lower than aerobically packaged $\mathrm{mMB}$. However the mean $\mathrm{pH}$ values were not significantly different for vacuum and aerobic packaging. Sahoo $\&$ Anjaneyulu ${ }^{21}$ also reported a non-significant difference in $\mathrm{pH}$ of buffalo meat nuggets due to vacuum packaging.

Cooking yield: The results of cooking determinants as given in Table 2 clearly indicate that the control showed lower cooking yield than $\mathrm{s}_{1}$ and $\mathrm{s}_{2}$ samples. Cooking yield increased significantly with the increasing levels of TP $(p<0.05)$. Increase in cooking yield occurred because TP contains soluble dietary fibers which have a high water holding and binding capacity and retains moisture and fat in the matrix. This finding is supported by the previous work of Aleson Carbonell et al., ${ }^{24}$ on the incorporation of lemon albedo fibers in beef patty formulation which showed that dietary fibers increased cooking yield, because of their ability to keep moisture and fat in the matrix.

Color value: The effect of packaging and storage period on color attributes of cooked $\mathrm{mMB}$ is given in Table 3. Addition of TP increased $\mathrm{L}^{*}$ (lightness) and $\mathrm{a}^{*}$ (redness) values of all treated $\mathrm{mMB}$ compared to control sample. Lightness $\left(\mathrm{L}^{*}\right)$ value showed a nonsignificant decreasing trend during refrigerated storage in control as well as treated $\mathrm{mMB}$ under aerobic and vacuum packaging. Redness $\left(a^{*}\right)$ and yellowness $\left(b^{*}\right)$ values also decreased during storage but the decrease was significant $(\mathrm{P} \leq 0.05)$ at the end of storage period. Similar effect on redness and yellowness during storage was shown by Devatkal et al., ${ }^{25}$ in chicken patties. Mean hue values showed a non-significant increasing trend with storage interval in control as well as in treated product while chroma values decreased significantly $(\mathrm{P} \leq 0.05)$ with storage intervals. These results are in agreement with the findings of Devatkal et al. ${ }^{25}$ in chicken patties incorporated with know and pomegranate fruit by-products. Color difference in vacuum packaged mMB was less as compared to aerobically packaged mMB. This indicates the useful effect of vacuum packaging in minimizing the color loss during the storage. 


\section{Antioxidant parameters}

Total phenolic content and DPPH (\% inhibition) activity: The results obtained for the total phenolic contents of $\mathrm{mMB}$ are presented in Figure 1. The overall changes in phenolic content indicated a significant decrease in phenolics during storage. Decrease of total phenolics during storage was significantly $(\mathrm{P} \leq 0.05)$ higher in control as compared to treated $\mathrm{mMB}$. This indicates $\mathrm{s}_{2}$ showed significantly higher phenolics during storage than $\mathrm{s}_{1}$ and control sample. Similarly, Naveena et al. ${ }^{26}$ have reported a significant increase in phenolic content of cooked chicken patties treated with pomegranate juice and rind extract. Recently, Devatkal et al., ${ }^{27}$ have also reported the higher phenolic content of goat meat patties treated with KRP, PRP and PSP extracts. From the data reported in Figure 2, the radical scavenging activity $(\mathrm{DPPH} \%) \mathrm{s}_{2}$ demonstrated significantly $(\mathrm{P}<0.05)$ greater free radical activity than control and $\mathrm{s}_{1}$ throughout storage period. However, both treated and control showed significant decrease in radical scavenging activity with increase in storage period. Our results are in agreement with Mamdouh et al. ${ }^{28}$ who reported a significant decrease in DPPH scavenging activity of chicken breast meat with increasing storage period. It is also clear that DPPH scavenging activity in case of vacuum packaged TP treated $\mathrm{mMB}$ was higher than both aerobically packaged TP treated and control mMB, showing the improved oxidative stability of $\mathrm{mMB}$ in vacuum. Similar results were shown by Meilnik et al., ${ }^{29}$ in turkey meat.

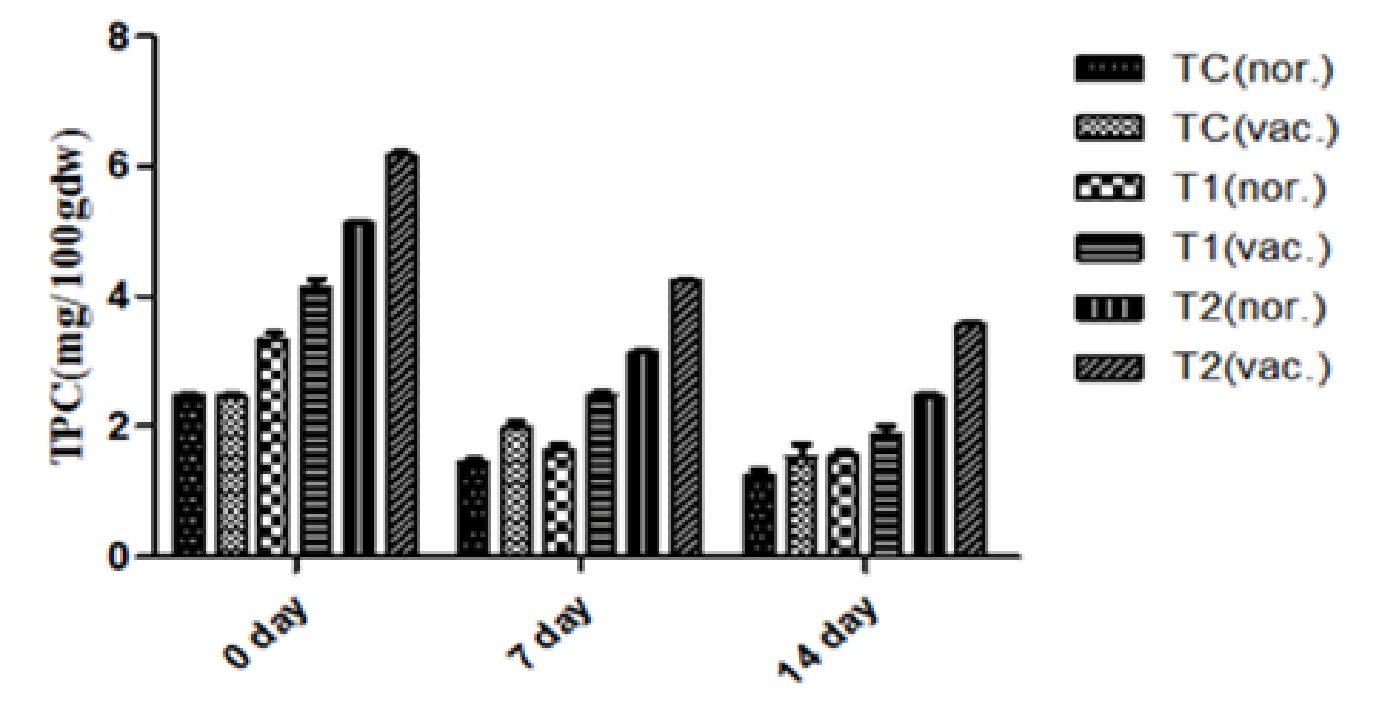

Figure I TPC of the value added MMB during refrigerated storage $\left(4 \pm I^{\circ} \mathrm{C}\right)$.

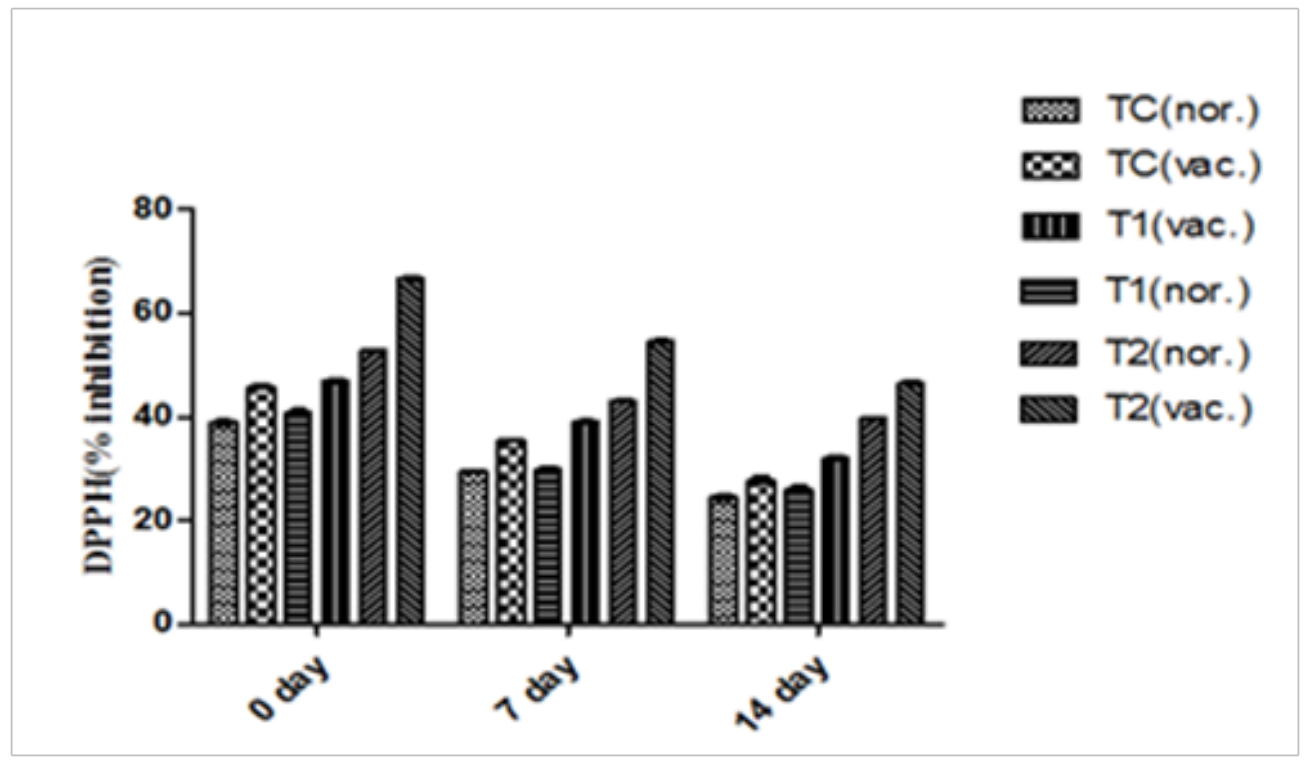

Figure $2 \mathrm{DPPH}$ of the value added MMB during refrigerated storage $\left(4 \pm 1^{\circ} \mathrm{C}\right)$. 
Sensory evaluation: The mean values of various sensory parameters (appearance, flavor, texture and overall acceptability) of vacuum and aerobically packed $\mathrm{mMB}$ incorporated with $3 \%$ and $6(\%)$ levels of $\mathrm{TP}$ and of control during refrigerated storage $\left(4 \pm 1^{\circ} \mathrm{C}\right)$ are presented in Table 4 . The sensory attributes were significantly affected during 20days of refrigerated storage and all the sensory parameters viz. appearance, flavor, texture and overall acceptability followed a decreasing trend with the storage. However treated product retained better sensory attributes than control sample throughout storage.

Table 4 Sensory attributes of value mutton meat balls during refrigerated storage $\left(4 \pm I^{\circ} \mathrm{C}\right)$

All values are mean \pm standard deviation of three replicates.

Means in the same column with different superscripts differ significantly: $* \mathrm{P}<0.05$.

C control without TP, $\mathrm{S}_{1}$ with $3 \% \mathrm{TP}, \mathrm{S}_{2}$ with $6 \% \mathrm{TP}$.

\begin{tabular}{|c|c|c|c|c|c|c|c|}
\hline \multirow{2}{*}{ Parameter } & \multirow{2}{*}{ Storage days } & \multicolumn{6}{|l|}{ Treatment } \\
\hline & & C (nor.) & C (vac.) & SI (nor.) & SI (vac.) & S2 (nor.) & S2 (vac.) \\
\hline \multirow{3}{*}{ Appearance } & 0 & $6.08 \pm 0.06^{a}$ & $6.23 \pm 0.97^{\mathrm{b}}$ & $6.28 \pm 0.34^{\mathrm{ab}}$ & $6.56 \pm 0.14^{\mathrm{ac}}$ & $6.83 \pm 0.98^{\mathrm{ab}}$ & $7.83 \pm 0.75^{\mathrm{ac}}$ \\
\hline & 7 & $6.00 \pm 0.97^{\mathrm{b}}$ & $6.13 \pm 0.76^{c}$ & $6.35 \pm 0.25^{\mathrm{ac}}$ & $6.49 \pm 0.09^{a}$ & $6.73 \pm 0.54^{b}$ & $7.73 \pm 0.35^{c}$ \\
\hline & 14 & $5.93 \pm 0.97^{f}$ & $6.03 \pm 0.97^{e}$ & $6.14 \pm 0.33^{\mathrm{a}}$ & $6.33 \pm 0.18^{c}$ & $6.53 \pm 0.34^{c}$ & $7.38 \pm 0.28^{d}$ \\
\hline \multirow{3}{*}{ Flavor } & 0 & $6.67 \pm 0.78^{c}$ & $6.56 \pm 0.82^{\mathrm{a}}$ & $6.67 \pm 0.0 \mathrm{I}^{\mathrm{c}}$ & $6.7 I \pm 0.43^{d}$ & $6.79 \pm 0.82^{\mathrm{ac}}$ & $8.50 \pm 0.84^{f}$ \\
\hline & 7 & $6.07 \pm 0.82^{\mathrm{ab}}$ & $6.29 \pm 0.82^{\mathrm{ac}}$ & $6.44 \pm 0.06^{b}$ & $6.56 \pm 0.17^{f}$ & $7.50 \pm 0.84^{\mathrm{a}}$ & $7.77 \pm 0.68^{e}$ \\
\hline & 14 & $5.79 \pm 0.52^{\mathrm{ab}}$ & $5.67 \pm 0.72^{\mathrm{ac}}$ & $5.78 \pm 0.46^{\mathrm{a}}$ & $5.91 \pm 0.05^{d}$ & $6.50 \pm 0.84^{b}$ & $6.99 \pm 0.08^{b}$ \\
\hline \multirow{3}{*}{ Texture } & 0 & $7.08 \pm 0.02^{\mathrm{b}}$ & $7.18 \pm 0.02^{\mathrm{a}}$ & $7.21 \pm 0.12^{c}$ & $7.28 \pm 0.45^{b}$ & $7.35 \pm 0.05^{c}$ & $7.46 \pm 0.02^{\mathrm{b}}$ \\
\hline & 7 & $6.06 \pm 0.08^{c}$ & $6.18 \pm 0.06^{a}$ & $6.29 \pm 0.05^{b}$ & $6.35 \pm 0.18^{a}$ & $6.48 \pm 0.05^{\mathrm{a}}$ & $6.98 \pm 0.02^{\mathrm{ab}}$ \\
\hline & 14 & $5.57 \pm 0.02^{\mathrm{ab}}$ & $6.18 \pm 0.02^{c}$ & $6.13 \pm 0.36^{f}$ & $6.11 \pm 0.29^{a b}$ & $6.25 \pm 0.05^{c}$ & $6.78 \pm 0.02^{\mathrm{ac}}$ \\
\hline \multirow{3}{*}{ Overall Acc. } & 0 & $7.10 \pm 0.26^{f}$ & $7.20 \pm 0.20^{\mathrm{ab}}$ & $7.23 \pm 0.16^{\mathrm{ac}}$ & $7.29 \pm 0.13^{\mathrm{a}}$ & $7.30 \pm 0.19^{b}$ & $7.90 \pm 0.98^{d}$ \\
\hline & 7 & $6.40 \pm 0.16^{d}$ & $6.60 \pm 0.20^{\mathrm{bc}}$ & $6.65 \pm 0.09^{c}$ & $6.75 \pm 0.17^{b}$ & $6.80 \pm 0.26^{f}$ & $7.00 \pm 0.16^{\mathrm{a}}$ \\
\hline & 14 & $6.10 \pm 0.20^{c}$ & $6.20 \pm 0.20^{d}$ & $6.34 \pm 0.06^{b}$ & $6.56 \pm 0.13^{\mathrm{ac}}$ & $7.08 \pm 0.14^{c}$ & $7.30 \pm 0.13^{b}$ \\
\hline
\end{tabular}

The decrease in appearance scores might be due to the pigment and lipid oxidation resulting in non-enzymatic browning. A decrease in appearance and color scores of meat products with increase in storage period was also reported by Bhat et al., ${ }^{30}$ in chicken seekh kababs. A gradual decline of flavor might be due to the expected loss of volatile flavor components from spices and condiments on storage. The progressive decrease in flavor could be correlated to increase in thiobarbituric acid reacting substances value of meat products. Decline in flavor scores of meat products during storage were reported by Thomas et al., ${ }^{31}$ in buffalo meat nuggets. Texture scores followed a decreasing trend throughout the period of storage. However, scores were comparable in treated and control products throughout the storage period.
The lower textural scores might be due to loss of water during storage and subsequent reduction of $\mathrm{pH}$ and denaturation of proteins at low $\mathrm{pH}$ and degradation of muscle fiber proteins by bacterial action, which resulted in decreased water binding capacity. Similar results were presented by Kilinc ${ }^{32}$ in anchovy patties during refrigerated storage, respectively. The overall acceptability scores of both control and the treated $\mathrm{mMB}$ decreased significantly as the storage progressed. This decrease might be reflective of the decline in scores of flavor, texture attributes. Similar findings have also been reported by Kumar \& Sharma ${ }^{33}$ for various meat products. These observations indicated that $\mathrm{mMB}$ incorporated with $4 \%$ percent TP retained very good sensory attributes up to day 20 under refrigerated storage at $4 \pm 1^{\circ} \mathrm{C}$ with significant effect of vacuum packaging compared to aerobic one. ${ }^{34,35}$ 


\section{Conclusion}

Generally, incorporation of minced chicken meat with TP after processing proved to be advantageous with regard to lipid stability of processed chicken meat, under refrigeration especially in vacuum packed than aerobic. The effect of the TP level increased with increasing antioxidant concentration in the experimental products. The addition of TP combined with vacuum packaging should be considered as a good method to improve lipid stability and overall quality attributes in $\mathrm{mMB}$.

\section{Acknowledgements}

None.

\section{Conflict of interest}

The author declares no conflict of interest.

\section{References}

1. Østerlie M, Lerfall J. Lycopene from tomato products added to minced meat: effect on storage quality and colour. Food Research International. 2005;38(8-9):925-929.

2. Lisa T. The top 10 Antioxidant foods. Back to Nutrition Archives. 2002:1-3.

3. Eyiler E, Oztan A. Production of frankfurters with tomato powder as a natural additive. LWT-Food Science and Technology. 2011;44(1):307311.

4. Verma AK, Rajkumar V, Banerjee R, et al. Guava (Psidium guajava L.) Powder as an Antioxidant Dietary Fiber in Sheep Meat Nuggets AsianAustralas. J Anim Sci. 2013;26(6):886-895.

5. Official methods of analysis. 17th ed. USA: Association of Official Analytical Chemists; 2000.

6. Official Method of Analysis. 18th ed. USA: Association of Official Analytical Chemists; 2005.

7. Du M, Ahn DU. Effect of antioxidants on the quality of irradiated sausages prepared with turkey thigh meat. Poult Sci. 2002;81(8):12511256.

8. Koniecko R. Handbook of meat chemists. USA: Avery Publishing Group; 1979. p. 53-55.

9. Singleton VL, Rossi JA. Colorimetry of total phenolics with phosphomolybdic phosphotungstic acid reagents. American Journal of Enology and Viticulture. 1965;16:144-158.

10. Blois MS. Antioxidant determination by the use of a stable free radical. Nature. 1958;181:1199-1200.

11. Deda MS, Bloukas JG, Fista GA. Effect of tomato paste and nitrite level on processing and quality characteristics of frankfurters. Meat Sci. 2007;76(3):501-508.

12. El-Gharably AMA, Ashoush IS. Utilization impact of adding pomegranate rind powder and red beet powder as natural antioxidant on quality characteristics of beef sausage. World Journal of Dairy and Food Science. 2011;6(1):86-97.

13. Fernandez-Gines JM, Fernandez-Lopez J, Sayas-Barbera E, et al. Lemon albedo as a new source of dietary fiber: application to bologna sausages. Meat Sci. 2004;67(1):7-13.

14. Verma AK, Sharma BD, Banerjee R. Effect of sodium chloride replacement and apple pulp inclusion on the physicochemical, textural and sensory properties of low fat chicken nuggets. LWT-Food Science and Technology. 2010;43(4):715-719.
15. Trout ES, Hunt NC, Johnson DE, et al. Chemical, physical and sensory characteristics of ground beef containing 5-30 per cent fat. Journal of Food Science. 1992;57(1):25-29.

16. Huang SC, Shiau CY, Liu TE, et al. Effects of rice bran on sensory and physicochemical properties of emulsified pork meatballs. Meat Science. 2005;70(4):613-619.

17. Li Y, Guo C, Yang J, et al. Evaluation of antioxidant properties of pomegranate peel extract in comparison with pomegranate pulp extract. Food Chemistry. 2006;96(2):254-260.

18. Banerjee R, Verma AK, Das AK, et al. Antioxidant effects of broccoli powder extract in goat meat nuggets. Meat Science. 2012;91(2):179-184.

19. Devatkal SK, Thorat P, Manjunatha M. Effect of vacuum packaging and pomegranate peel extract on quality aspects of ground goat meat and nuggets. J Food Sci Technol. 2012;51(10):2685-2691.

20. Kanatt SR, Paul P, D'Souza SF, et al. Lipid peroxidation in chicken meat during chilled storage as affected by antioxidants combined with lowdose gamma irradiation. Journal of Food Science. 1998;63(2):198-200.

21. Sahoo J, Anjaneyulu ASR. Effect of alpha tocopherol acetate preblending on the quality of ground buffalo meat. Food Chemistry. 1997;60(3):397402 .

22. Viuda-Martos M, Ruiz-Navajas Y, Fernandez-Lopez J, et al. Effect of orange dietary fiber, oregano oil and packaging conditions on shelf-life of bologna sausages. Food Control. 2010;21(4):436-443.

23. Georgantelis D, Ambrosiadis I, Katikou P, et al. Effect of rosemary extract, chitosan and $\alpha$-tocopherol onmicrobiological parameters and lipid oxidation of fresh pork sausages stored at $4^{\circ} \mathrm{C}$. Meat Science. 2007;76(1):172-181.

24. Aleson-Carbonell L, Fernandez-Lopez J, Perez-Alvarez JA, et al. Functional and sensory effects of fiber rich ingredients on breakfast fresh sausages manufacture. Journal of Food Science and Technology International. 2005;11(2):89-97.

25. Devatkal SK, Narsaiah K, Borah A. The effect of salt, extract of kinnow and pomegranate fruit by-products on colour and oxidative stability of raw chicken patties during refrigerated storage. J Food Sci Technol. 2011;48(4):472-477.

26. Naveena BM, Sen AR, Vaithiyanathan S, et al. Comparative efficacy of pomegranate juice, pomegranate rind powder extract and BHT as antioxidants in cooked chicken patties. Meat Science. 2008;80:1304 1308 .

27. Devatkal SK, Narsaiah K, Borah A. Antioxidant effect of extracts of kinnow rind, pomegranate rind and seed powders in cooked goat meat patties. Meat Sci. 2010;85(1):155-159.

28. Mamdouh A, Hassanin Mervat S, Abdel-Moneim, et al. The effect of using Chamomile extract for the preservation of chicken breast meat on oxidative parameters and microbial profile of chicken meat. African Journal of Agricultural Science and Technology. 2015;3(10):419-424.

29. Mielnik MB, Olsen E, Vogt G, et al. Grape seed extract as antioxidant in cooked, cold stored turkey meat. LWT-Food Science and Technology. 2006;39(3):191-198.

30. Bhat ZF, Kumar P, Kumar S. Effect of skin, enrobing and refrigerated storage on the quality characteristics of chicken meat balls. J Food Sci Technol. 2013;50(5):890-899.

31. Thomas R, Anjaneyulu ASR, Kondaiah N. Quality and shelf life evaluation of emulsion and restructured buffalo meat nuggets at cold storage $\left(4 \pm 1^{\circ} \mathrm{C}\right)$. Meat Sci. 2006;72(3):373-379.

32. Kilinc B. Microbiological, sensory and color changes of anchovy (Engraulis encrasicholus) patties during refrigerated storage. Journal of Muscle Foods. 2009;20(2):129-137. 
33. Kumar RR, Sharma BD. Storage quality and shelf life of aerobically packaged extended chicken patties. Journal of Veterinary Public Health. 2004;2(1-2):35-41

34. Mirzaei-Aghsaghali A, Maheri-Sis N, Mansouri H, et al. Evaluating potential nutritive value of pomegranate processing by-products for ruminants using in vitrogas production technique. ARPN Journal of Agriculture and Biological Sciences. 2011;6(6):45-51.
35. Anjaneyulu ASR, Lakshmanan V, Sharma N, et al. Buffalo meat production and meat quality. A review-Indian Food Packer. 1990;44(4):21-31. 